\title{
Flora of Espírito Santo: Psidium (Myrtaceae)
}

\author{
Amélia C. Tuler ${ }^{1,3}$, Tatiana T. Carrijo ${ }^{2}$, Márcia F.S. Ferreria ${ }^{2}$ \& Ariane L. Peixoto $^{1}$
}

\begin{abstract}
This study presents a floristic-taxonomic treatment of Psidium in the state of Espírito Santo, and is a result of fieldwork combined with analyses of herbarium specimens. Fourteen species of the genus were recognized in Espírito Santo state (P. brownianum, P. cattleianum, P. cauliflorum, P. guajava, P. guineense, P. longipetiolatum, P. myrtoides, P. oblongatum, P. oligospermum, P. ovale, P. rhombeum, P. rufum P. sartorianum, and Psidium sp.), accounting for about 34\% of the species richness estimated for the genus in the Atlantic Rainforest biome. The species occur predominantly in lowland forests up to 700 meters above sea level. These areas are highly threatened due to urbanization of coastal areas and agricultural expansion in the state Espírito Santo. Therefore, the conservation of Psidium species in this state requires the creation of more lowland protected areas.
\end{abstract}

Key words: Atlantic Rainforest, diversity, Myrteae, taxonomy.

\section{Resumo}

Este estudo apresenta o tratamento florístico-taxonômico para o gênero Psidium no estado do Espírito Santo, e resulta de trabalho de campo, combinado à análise de espécimes de herbário. Quatorze espécies do gênero foram reconhecidas no Espírito Santo ( $P$. brownianum, P. cattleianum, P. cauliflorum, P. guajava, $P$. guineense, $P$. longipetiolatum, $P$. myrtoides, $P$. oblongatum, $P$. oligospermum, $P$. ovale, $P$. rhombeum, P. rufum P. sartorianum e Psidium sp.), representando cerca de $34 \%$ da riqueza de espécies estimada para o gênero na Floresta Atlântica. As espécies ocorrem predominantemente em florestas baixas, até 700 metros. Essas áreas são altamente ameaçadas devido à urbanização das áreas costeiras e a expansão da agricultura do estado do Espírito Santo. Desta forma, a conservação das espécies de Psidium neste estado implica na criação de mais áreas de preservação em compreendendo florestas baixas.

Palavras-chave: Floresta Atlântica, diversidade, Myrteae, taxonomia.

\section{Introduction}

Psidium L. has been one of the most difficult genera to define within the American species of Myrtaceae (Landrum \& Sharp 1989). The genus circumscription includes characteristics as solitary flowers or flowers disposed in small racemes, dichasia or botryoids; the flowers have a calyx with lobes either entirely fused or almost fused, breaking in irregular lobes or a calyptra, ovary with 2-5 locules on a peltate to lamellate intrusive placenta; seeds with bony testa and cochlear embryo with small cotyledons and large hypocotyl (Landrum \& Kawasaki 1997; McVaugh 1968). However, not all species of Psidium exhibit this set of traits, which has led to taxonomic confusion. This has direct implications for the understanding of species in local and regional studies.

The monograph of Berg (1857-1859) in Flora brasiliensis is the main contribution to the knowledge of the Brazilian species of Psidium. In this study, the genus was divided into six sections, delimited by morphological characters such as leaf texture, calyx shape and number of locules in the ovary. Since then, several new species were described (Landrum \& Sobral 2006; Soares-Silva \& Proença 2006, 2008), without a new broad taxonomic revision. However, regional and local floras carried out for Myrtaceae especially in

\footnotetext{
${ }^{1}$ Instituto de Pesquisas Jardim Botânico do Rio de Janeiro, Escola Nacional de Botânica Tropical, R. Pacheco Leão 2040, 22460-030, Horto, Rio de Janeiro, RJ, Brazil.

${ }^{2}$ Universidade Federal do Espírito Santo, Centro de Ciências Agrárias, Depto. Biologia, 29500-000, Guararema, Alegre, ES, Brazil.

${ }^{3}$ Author for correspondence: ameliatuler@gmail.com
} 
Atlantic Rainforest biome (Barroso \& Peron 1994; Kawasaki 1989; Legrand \& Klein 1977; Morais \& Lombardi 2006; Sobral 2003; Souza \& Morim 2008) have added much information about the richness and morphology of the species in Brazil.

About 60 taxa of Psidium were recorded in the different Brazilian biomes, with 17 (28\%) restricted to the Atlantic Rainforest (BFG 2015). The state of Espírito Santo, which lies entirely within the Atlantic Rainforest, is considered strategic for conservation of Myrtaceae due to the great diversity revealed in floristic studies in restinga vegetation (Pereira \& Araújo 2000; Giaretta et al. 2015); montane forest (Saiter et al. 2011) and tabuleiro forest (Jesus \& Rolim 2005). Taxonomic surveys with Myrtaceae were carried out especially in protected areas (Barroso \& Peixoto 1995; Sobral et al. 2009; Mazine \& Souza 2007; Giaretta \& Peixoto 2015), and a recent study identified SSR markers with potential for Psidium species molecular delimitation (Tuler et al. 2015). However, the genus was never studied under a floristic survey. Aiming to fill this gap, we present this taxonomic study for Psidium in the Espírito Santo state, providing descriptions, key for species identifications, and species distribution.

\section{Materials and Methods}

\section{Study area}

The Espírito Santo state (ES) is located in southeastern Brazil entirely within the Atlantic Rainforest biome (Fig. 1). Three major vegetation formations occur in $\mathrm{ES}$, in three distinct geomorphological provinces (Antongiovanni \& Coelho 2005; Dutra et al. 2015): lowland coastal vegetation or restinga vegetation (formed by

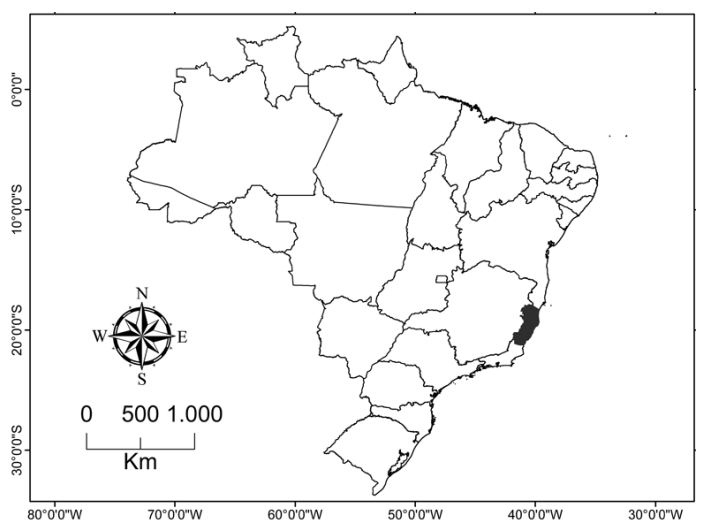

Figure 1 - Localization of the Espírito Santo state in Southeastern Brazil. deposition of sandy sediments of the quaternary), tabuleiro forest (characterized by flat relief with small slopes formed by continental and quaternary sediments) and montane forest (by mountainous areas on Precambrian crystalline rocks). Considering that, the fieldwork covered 13 locations in ES between 2012 and 2014. The expeditions were carried out in representative locations of restinga vegetation (Itaúnas State Park, mun. of Conceição da Barra and Paulo Cézar Vinha State Park, mun. of Guarapari, Municipal Park of Jacarenema, mun. of Vila Velha); tabuleiro forest (Vale Natural Reserve, mun. of Linhares, Sooretama Biological Reserve, mun. of Sooretama, Córrego Grande Biological Reserve, mun. of Conceição da Barra), and montane forest (Caparaó National Park, mun. of Dores do Rio Preto; Vista Alegre, mun. of Iúna, Santa Lúcia Biological Station and Augusto Ruschi Biological Station, mun. of Santa Teresa, Experimental area of the Universidade Federal do Espírito Santo, mun. of Alegre, Mata das Flores State Park, mun. of Castelo, Piaçu, mun. of Muniz Freire, and Pacotuba National Forest mun. of Cachoeiro do Itapemirim).

Morphological analysis and distribution

The samples of fertile branches were collected and dried according to Peixoto \& Maia (2013). The species were identified using taxonomic revisions and floras for Central and South America (e.g., Berg 1857-1859; McVaugh 1958; McVaugh 1963; Legrand \& Klein 1977; Kawasaki 1989; Barroso \& Peron 1994; Barroso \& Peixoto 1995; Sobral 2003; Souza \& Morim 2008; Sobral 2007; Giaretta \& Peixoto 2015) and type collections. The species were analysed and described at the Laboratório de Botânica of the Universidade Federal do Espírito Santo. Concepts and terminology used to describe the species follow Hickey \& King (2000) and Radford et al. (1974). One specimen per municipality was listed as selected material, and additional collections from other states were listed when necessary. Voucher materials were included in the herbarium RB with duplicates for VIES, MBML and CVRD (acronyms following Thiers, continuously updated). The analysis of herbarium vouchers from RB, R, VIES, MBML, BHCB, CVRD and UB followed traditional methods in plant taxonomy (Hickey \& King 2000; Radford et al. 1974). The species distribution maps were prepared using the Diva-Gis 5.2 applicative (Hijmans et al. 2005). 


\section{Results and Discussion}

Fourteen species of Psidium were registered in Espírito Santo (Figs. 1-5): Psidium brownianum Mart. ex DC., P. cattleianum Sabine, P. cauliflorum Landrum \& Sobral, P. guajava L., P. guineense Sw., P. longipetiolatum D. Legrand, $P$. myrtoides O. Berg, P. oblongatum O. Berg, P. oligospermum DC, P. ovale (Spreng.) Burret, P. rhombeum O. Berg, P. rufum Mart. ex DC., P. sartorianum (O. Berg) Nied., and Psidium sp. This last species is still under investigation. This number comprises about $36 \%$ of the Psidium species richness in the Atlantic Rainforest. Most of species occur in tabuleiro forest (11 spp.) and montane forest (12 spp.), being four and two species endemic to these environments, respectively. Six species occur in the restinga vegetation.

The species of Psidium in ES can be distinguished from each other mainly by the combination of vegetative (shape and number of secondary veins of the leaves) and reproductive characters (shape and size of fruits, number of locules and seeds). Psidium rhombeum was initially considered endemic to northeastern Brazil, known only from the Caatinga biome in the state of Bahia (BFG 2015), but its distribution is here expanded to Espírito Santo. In Espírito Santo, species of Psidium occur predominantly in lowland forests up to $700 \mathrm{~m}$ above sea level. This is worrying because these lowland forests are highly threatened due to urbanization of coastal areas and agriculture expansion (Paula 2006).

Psidium L., Sp. Pl. 1: 470. 1753.

Trees or shrubs, glabrous, glabrescent or sparsely to densely pubescent; branches cylindrical or tetragonal; leaves simple and opposite, exhibiting typical brochidodromous venation; elliptic, cordate, oblong or obovate, chartaceous or coriaceous, glabrous, glabrescent or sparsely to densely pubescent, margin entire, revolute or slight revolute, midvein slightly sulcate above and prominent below. Flowers solitary, axillary racemes, dichasium, panicle or inflorescence growing from auxotelic axis producing vegetative shoots with adult leaves after anthesis; floral buds pyriform, entire or constricted above the ovary, round or apiculate, calyx with lobes entirely or partially fused, tearing irregularly at anthesis, 4-5 lobed, pentamerous flowers; calyx cupuliform or calyptrate, petals free, numerous stamens; ovary inferior, with two to five locules and few to many ovules per locule on a peltate to lamellate intrusive placenta. Fruits with many seeded, seeds with a bony testa and a cochlear embryo with small cotyledons and a large hypocotyl.

\section{Identification key for Psidium in Espírito Santo}

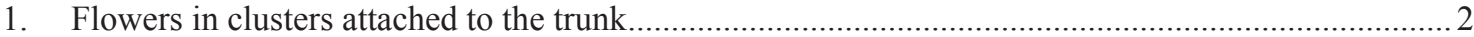

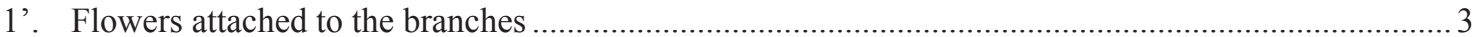

2. Young branches, leaves, inflorescences and fruits densely pubescent.........3. Psidium cauliflorum

2'. Young branches, leaves, inflorescences and fruits glabrous ................................. 14. Psidium $\mathrm{sp}$.

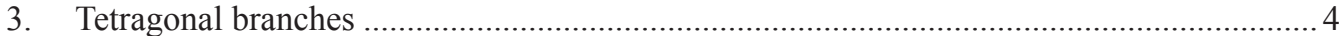

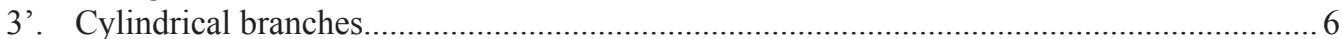

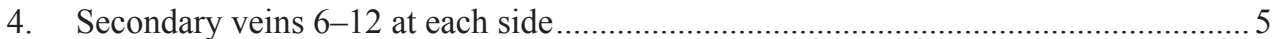

4'. Secondary veins 12-18 at each side............................................. 4. Psidium guajava

5. Flower buds pyriform, constricted, calyx with lobes entirely fused

5. Psidium guineense

5'. Flower buds pyriform, not constricted and partially fused ....... 12. Psidium rufum

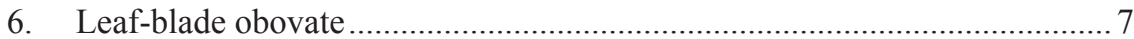

6'. Leaf-blade elliptic, cordate, ovate or rhomboid .......................................... 8

7. Petioles 3.2-10(-15) $\mathrm{mm}$ long, leaf/petiole length 9:1

2. Psidium cattleianum

7'. Petioles (10-)12-25 mm long, leaf/petiole length 5:1

6. Psidium longipetiolatum

8. Fruits with up to five seeds

8'. Fruits with more than five seeds................................................. 10

9. Fruits $4.8-5 \times 4.5-5 \mathrm{~mm}$, globose............ 10. Psidium ovale

9'. Fruits $16-21 \times 6-12 \mathrm{~mm}$, pyriform or rounded.

9. Psidium oligospermum 


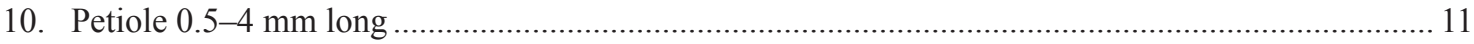

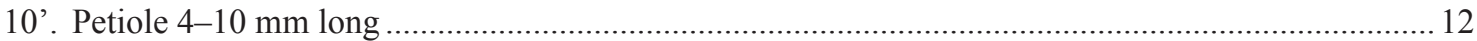

11. Tree 20-28 m, elliptic or obovate leaves $2.1-5.8 \times 0.8-2.2 \mathrm{~cm}$, rounded fruits $11-15 \times 9-14 \mathrm{~mm}$ 13. Psidium sartorianum

11'. Tree or shrub $0.5-8 \mathrm{~m}$, elliptic ovate or cordate leaves $1.7-10 \times 0.8-7 \mathrm{~cm}$, elliptic or rounded fruits $7-15 \times 2.6-11 \mathrm{~mm}$. 1. Psidium brownianum

12. Fruits $9-16 \times 5.5-14 \mathrm{~mm}$, angular seeds $4-10$ per fruit 13

12 '. Fruits $38-53 \times 26-56.5 \mathrm{~mm}$, rounded seeds $15-20$ per fruit.

13. Leaf-blade elliptic or obovate $2.5-11 \times 1-4.5 \mathrm{~cm}$ 8. Psidium oblongatum

13'. Leaf-blade rhomboid $6.3-7 \times 3.1-3.5 \mathrm{~cm}$.

1. Psidium brownianum Mart. ex DC., Prodr., 3: 236. 1828. Figs. 2a-e; 5a

Tree or shrub, $0.5-8 \mathrm{~m}$ tall; glabrous, cylindrical branches, $1-4.7 \mathrm{~mm}$ diam.; petiole $0.5-4$ $\times 0.5-3 \mathrm{~mm}$; leaf-blade cordate or elliptic, $1.7-10$ $\times 0.8-7 \mathrm{~cm}$, carthaceous or coriaceous, glabrous, apex acute or obtuse, base obtuse, subcordate, rare acute, margin entire, slightly revolute, midvein slightly sulcate above and prominent below; $6-12$ secondary veins at each side, visible on both faces, brochidodromous, marginal vein $1-4 \mathrm{~mm}$ from the margin. Inflorescence terminal raceme, lateral or auxotelic axis producing vegetative shoots with adult leaves after anthesis, $1-8$ flowered; pedicels 3-13 mm long; bracts $0.5-2 \times 0.4-1 \mathrm{~mm}$, ovate or obovate, bracteoles $0.5-2 \times 0.3-1.2 \mathrm{~mm}$, both persistent after anthesis. Floral buds $2-5 \times 0.7-4$ $\mathrm{mm}$, pyriform, calyx with lobes entirely fused or partially fused, tearing in four irregular lobes, sepals 1-3 mm long, $0.8-3 \mathrm{~mm}$ wide, rounded, equal in size; petals $2-4 \mathrm{~mm} \times 2-3 \mathrm{~mm}$; stamens $1.5-4.5$ $\mathrm{mm}$ long, anthers globose, $0.3-1 \mathrm{~mm}$ long, rimose; ovary 2-locular, 10-12 ovules per locule. Fruits elliptic or rounded, 7-15 × 2.6-11 mm, glabrous, black when mature; seeds angular, $2.5-3 \mathrm{~mm}$ long, 8-12 per fruit.

Selected specimens: Águia Branca, 17.I.2008, fl., M.C. Souza 614 (MBML, RB). Aracruz, 12.XI.1992, fr., O.J. Pereira 2645 (VIES). Colatina, 17.IV.2006, fl., L.F.S. Magnago 793 (MBML). Conceição da Barra, 24.XII.2011, fr., M.M. Monteiro 127 (RB). Guarapari, 27.X.1987, fl., O.J. Pereira 1323 (VIES). Itapemirim, 10.V.1990, fl., P.C. Vinha 905 (VIES). Linhares, 9.II.2007, fr., G.S. Siqueira 305 (CVRD). Nova Venécia, 14.I.2009, fr., A.P. Fontana et al. 5766 (RB). Presidente Kennedy, 7.VIII.1990, fr., J.M.L. Gomes 1321 (VIES). São Mateus, 18.XI.2006, fr., A.O. Giaretta 05 (RB). Serra, 6.I.2000, fl., I.D. Rodrigues 05 (VIES). Vila Velha, 29.X.1997, fl., R.L. Dutra 293 (VIES). Vitória, 25.VI.1990, fr., P.C. Vinha 1042 (VIES, RB).

Psidium brownianum is recognizable by the cordate or elliptic and glabrous leaf-blade, and by the elliptic and black fruits when ripe. It resembles $P$. myrtoides due to the auxotelic inflorescence and leaf size, differing by its short petioles and elliptic or rounded fruits. Flowers and fruits were collected all year round. Psidium brownianum is endemic to Brazil, occurring in the states of Alagoas, Pernambuco, Bahia, Espírito Santo, Minas Gerais and Rio de Janeiro, in Caatinga, Cerrado and Atlantic Rainforest (BFG 2015). This is the most widespread species in Espírito Santo, occurring in areas of montane and tabuleiro forests, but is predominant in restinga vegetation, including within protected areas (Fig. 5a).

2. Psidium cattleianum Sabine, Trans. Hort. Soc. London 4: 317, 1821.

Figs. 1f-h; 5a

Tree or shrub, $0.7-15 \mathrm{~m}$ tall; glabrous; branches cylindrical, $0.5-6 \mathrm{~mm}$ diam.; petiole $5-15 \times 0.5-2.8 \mathrm{~mm}$, leaf-blade obovate, 3.2-14.5 $\times 1.3-8 \mathrm{~cm}$, chartaceous or coriaceous, glabrous, apex obtuse, rare acute, base cuneate; margin entire, slightly revolute, midvein slightly sulcate above and prominent below; 6-12 pairs of secondary veins, inconspicuous in the adaxial face, evident in the abaxial face, brochidodromous, marginal vein $1-3$ $\mathrm{mm}$ from the margin. Solitary flower; pedicels $3-18$ mm long; bracts $1-5 \times 1-2.5 \mathrm{~mm}$, ovate, caducous; bracteoles $2 \times 0.8-1 \mathrm{~mm}$ wide, persistent. Floral buds $5-12 \times 3.5-6 \mathrm{~mm}$, pyriform, apiculate, calyx partially fused, $4-5$ lobed, sepals $2-8 \times 2-10 \mathrm{~mm}$, rounded, equal in size, with sparse trichomes; petals 5-8 $\times 4-5 \mathrm{~mm}$; stamens 5-10 mm, anthers globose, 0.5-1 mm long, rimose; ovary 4-locular, 10-13 ovules per locule. Fruits rounded, 15-47 × 9-25 $\mathrm{mm}$, glabrous, yellow or red when mature; seeds angular, 5-6 mm long, 38-45 per fruit.

Selected specimens: Águia Branca, 23.IV.2004, fr., A.M. Assis 1013 (MBML,VIES). Aracruz, 9.XII.1992, fr., O.J Pereira 4387 (VIES, RB). Castelo, 9.IV.2009, fr., A.M.A. Amorim et al. 7820 (MBML, RB). Conceição da Barra, 9.I.2008, fl., D.A. Folli 5839 (CVRD). Domingos 

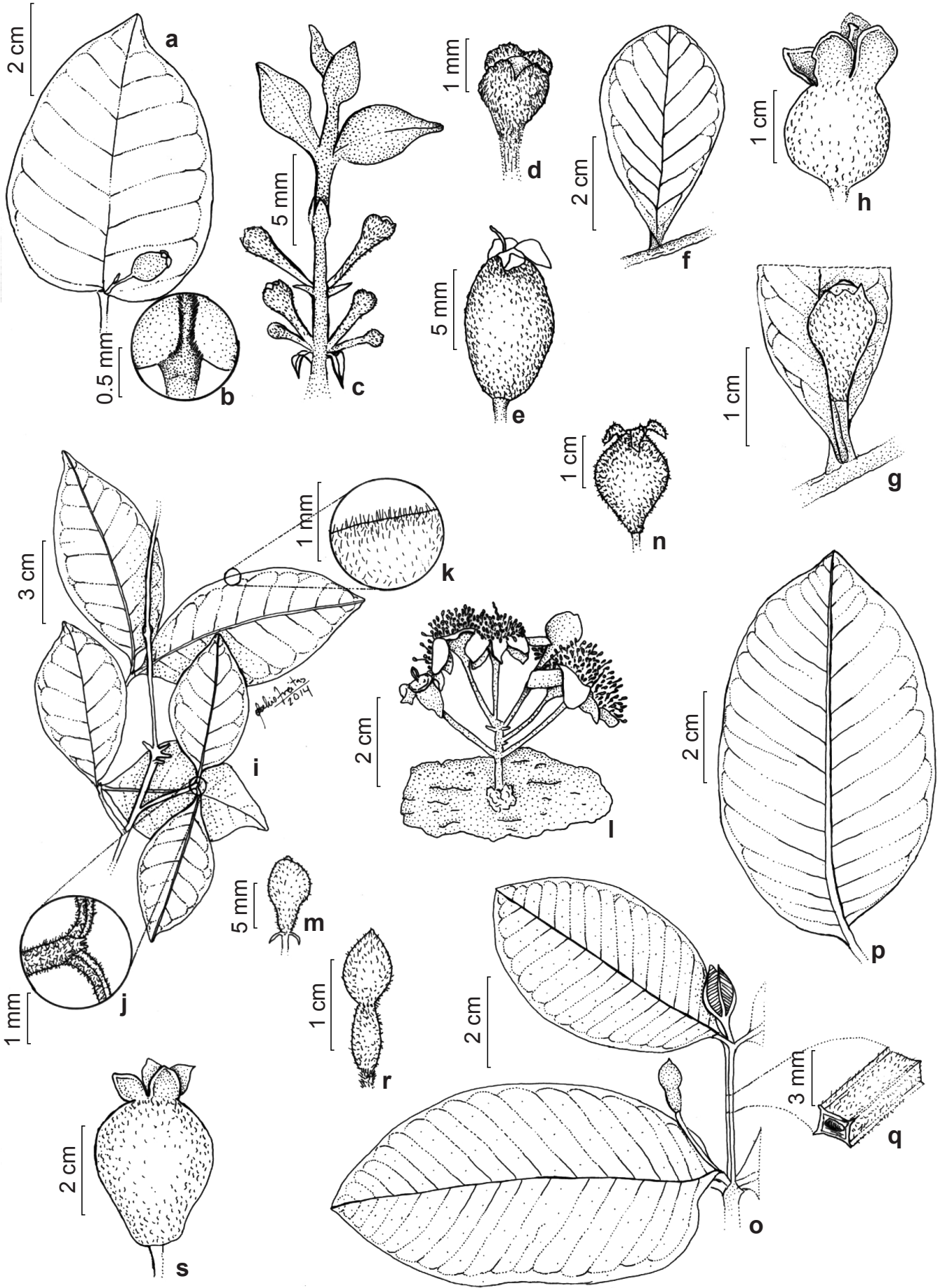

Figure 2 - a-e. Psidium brownianum - a. cordate leaves; b. cordate base; c. axillary inflorescences with 2-4 pairs of flowers with continuing vegetative growth; $d$. pyriform, partially fused floral buds; e. elliptic fruits. f-h. Psidium cattleianum - f. obovate leaves; g. pyriform, partially fused floral buds; h. rounded fruits. i-n. Psidium cauliflorum - i. branches; j,k. leaves sparsely to densely pubescent; 1 . flowers on the trunk; $m$. pyriform apiculate, densely pubescente floral buds; $n$. globose or pyriform fruits. o-s. Psidium guajava - o. axillary, uniflorous inflorescences; p. elliptic leaves (12-18 pairs of secondary veins); q. tetragonal branches; r. pyriform, constricted above the ovary, apiculated floral buds; s. pyriform fruits. (a,c. J.M.L. Gomes 1321; d,e. O. J. Pereira 802; J.E.Q. Faria 2498; f,h. A.C. Tuler 427; I,k.A.C. Tuler 480; 1,n.A.C. Tuler 455; o,r.D.A. Folli 3881; s. A.C. Tuler 496). 
Martins, 18.IV.2009, fr., D.A. Folli 6336 (CVRD). Guarapari, V.1998, fr., A.M. Assis 704 (VIES). Itaguaçu 10.IV.2004, fr., A.P. Fontana 873 (MBML, VIES). Itarana, 14.II.1999, fr., E.M. Nic Lughadha et al. 201 (RB). Linhares, 14.II.1999, fr., D.A. Folli 4920 (CVRD). Marilândia, 18.IV.2006, fr., L.F.S. Magnago et al. 834 (MBML, VIES). Santa Teresa, 19.VII.2003, fr., J. Rossini 458 (MBML, VIES). São Mateus, 28.III.1992, fr., V.D. Souza 318 (BHCB, CVRD). Vila Velha, 10.I.1993, fr., J.M.L. Gomes 1805 (VIES).

Psidium cattleianum can be recognized by its obovate leaf-blade and rounded and glabrous fruits, which are yellow or red when ripe. The fresh leaves are thick and glossy. This species is apparently closely related to $P$. longipetiolatum because of its leaf morphology, differing by the short petioles. Endemic to Brazil, it occurs in the states of Pernambuco, Ceará, Sergipe, Bahia, Espírito Santo, Rio de Janeiro, Minas Gerais, São Paulo, Paraná, Santa Catarina and the Rio Grande do Sul, in Caatinga, Cerrado and Atlantic Rainforest (BFG 2015). In the state of Espírito Santo, it is a widely distributed species, occurring within protected areas. The species was collected in areas of montane and tabuleiro forests, being predominant in restinga vegetation (Fig. 5a). Flowers from September to March, and fruits from November to August.

3. Psidium cauliflorum Landrum \& Sobral, Sida, 22: $927,2006$.

Figs. 1i-n; 5a

Tree, 5-7 m tall; sparsely to densely pubescent, hairs rusty brown to reddish; branches cylindrical, 1-3 mm diam., pubescent; petiole 2-4 $\times 1-1.5 \mathrm{~mm}$, leaf-blade elliptic, 4.7-10 × 2.2-4.7 $\mathrm{cm}$, chartaceous, sparsely pubescent, more densely so along midvein and leaf margin, apex acute or acuminate, base cuneate, margin entire, slightly revolute; midrib vein slightly sulcate above and prominent below; 7-13 secondary veins at each side, visible on both sides, brochidodromous, marginal vein 6-3 $\mathrm{mm}$ from the margin. Inflorescences in clusters or dichasia on older branches or trunk; pedicels, 1-4 mm long; bracts $1 \times 1 \mathrm{~mm}$, ovate, bracteoles $1-1.2 \times 0.2-0.3 \mathrm{~mm}$, both persistent. Floral buds $3-8 \times 2-5 \mathrm{~mm}$, pyriform, apiculate, densely pubescent, calyx with lobes entirely fused, tearing in four irregular lobes, sepals 5-6 × 2-5 $\mathrm{mm}$, irregular size and shape, trichomes sparse; petals 5-6 × 3-5 $\mathrm{mm}$; stamens 4-6 mm long, anthers globose $0.5-0.8 \mathrm{~mm}$ long, rimose; ovary 4-5 locular, 7-9 ovules per locule. Fruits rounded or slightly pyriform 15-21 × 13-16 mm, densely pubescent; vinaceous when mature; seeds angular, 4-6 mm long, 4 per fruit.
Selected specimens: Cachoeiro de Itapemirim, 7.I.2014, fl. and fr., A.C. Tuler et al. 485 (RB). Montanha, 29.XI.2012, fl., D.A. Folli 6961 (CVRD). Rio Bananal, 1.IV.2012, fl., J.E.Q. Faria 2535 (CVRD).

Psidium cauliflorum can be recognized by the rusty brown to reddish hairs covering the branches, petioles, leaves, flowers and fruits, and by the flowers attached to the trunk and older branches. This species resembles Psidium sp. due the cauliflorous inflorescence and leaf size, but Psidium sp. has glabrous inflorescences and fruits. Considered a rare species, $P$. cauliflorum is endemic of the Atlantic Rainforest (Funch et al. 2009; BFG 2015). This species was first described based on a specimen collected in Bahia and was recently found in Espírito Santo. In this state, this species is restricted to three localities in the heavily deforested montane forest areas, and has not been recorded within any protected area (Fig. 5a). It was collected in flower in January and April, and fruiting in May.

\section{Psidium guajava L. Sp. Pl.: 470. 1753.}

Figs. 1o-s; 5b

Tree or shrub, 1.8-8 m tall; glabrescent, branches tetragonal, $1.2-3.5 \mathrm{~mm}$ diam.; petiole $0.8-8 \times 1-1.5 \mathrm{~mm}$, leaf-blade elliptic or obovate, $3.5-11.5 \times 2.5-6 \mathrm{~cm}$, chartaceous or coriaceous, sparsely glabrescent, apex acute or obtuse, base acute or obtuse, margin entire, slightly revolute; midrib vein slightly sulcate above and prominent below; 12-18 pairs of secondary veins, evident on both sides, brochidodromous, marginal vein $1 \mathrm{~mm}$ from the margin. Solitary flower or dichasia, 1-3 flowered; pedicels 4-17 mm long, 1-2 mm wide; bracts $1.5-2 \times 1-2 \mathrm{~mm}$ wide, ovate or triangular, bracteoles $1.5-7 \times 0.3-0.5 \mathrm{~mm}$, ovate or linear, both caducous. Floral buds 10-18 × 4.5-7 mm, pyriform, constricted above the ovary, apiculate; calyx with lobes entirely fused, tearing irregularly at anthesis in 4-5 lobes, sepals 5-9 × 3-7 mm, irregular in size and shape, with sparse trichomes sparse; petals 6-15 × 5-10 mm; stamens 5-11 $\mathrm{mm}$, anthers globose, $0.7-1 \times 0.5-1 \mathrm{~mm}$, rimose; ovary 4-5 locular, 65-90 ovules per locule. Fruits rounded or pyriform, 23-25 × 12-21 mm, glabrous, yellow when mature; seeds angular, 3-4 mm long, 230-325 per fruit.

Selected specimens: Alegre, 16.10.2008, fl., D.R. Couto 1007 (MBML). Aracruz, 16.IV.2011, fr., C.L. Dalmonech 03 (MBML). Castelo, 2.V.2008, fr., C.N. Fraga et al. 1966 (RB). Linhares, 17.IV.2001, fl. and fr., D.A. Folli 3881 (CVRD). Mimoso do Sul, 31.III.2013, fr., M.F.S. Ferreira (VIES). São Mateus, 5.VI.1996, fl., M.C.F. Jesus 01 (VIES). Vitória, 12.X.1984, fl., A.G. Silva 618 (RB). 
Psidium guajava can be characterized by the quadrangular, branches, elliptic or obovate leaf-blade with $12-18$ pairs of secondary veins, floral buds pyriform and apiculate, and glabrous fruits. This species resembles $P$. guineense in leafblade shape and size, but is distinguishable by the greater number of secondary veins and apiculate floral buds. Psidium guajava is a species of great economic importance, cultivated worldwide. This species is naturalized in Brazil, occurring in almost all states (BFG 2015), and was found in cultivation or occurring spontaneously in disturbed areas in the state of Espírito Santo (Fig. 5b). It was collected in flower between June and October, and fruiting between March and May.

\section{Psidium guineense Sw. Prodr.,: 77, 1788.}

Figs. 3a-f; 5b

Tree or shrub, 1-6 $\mathrm{m}$ tall; densely pubescent, hairs rusty to brown, branches tetragonal, 1-4 mm diam.; petiole 3-14 $\mathrm{mm}$ long, $0.5-2.5 \mathrm{~mm}$ wide, leaf-blade elliptic or ovate, $3-16.7 \times 1.6-6.8 \mathrm{~cm}$, chartaceous or coriaceous, sparsely pubescent, more densely so along midvein and leaf margin, apex acute, obtuse or rounded, base acute or obtuse, margin entire, slightly revolute; midvein slightly sulcate above and prominent below; 6-12 pairs of secondary veins, evident on both faces, brochidodromous, marginal vein $0.5-2 \mathrm{~mm}$ from the margin. Solitary flower or dichasia, 1-3 flowered; pedicels $2-17 \times 0.3-2 \mathrm{~mm}$; bracts $1-3 \times$ $0.5-1 \mathrm{~mm}$ or linear, bracteoles $1.5-3 \times 0.4-1 \mathrm{~mm}$, ovate or linear. Floral buds 6-14 mm long, 4-6 $\mathrm{mm}$ wide, pyriform, constricted above the ovary, calyx with lobes entirely fused tearing irregularly at anthesis in 4-5 lobes, sepals 4-8 mm long, 2-8 $\mathrm{mm}$ wide, irregular in size and shape, puberulent; petals 7-13 × 4-11 mm; stamens 5-12 $\mathrm{mm}$, anthers globose 1-2 mm long, rimose; ovary 4-5 locular, 70-77 ovules per locule. Fruits rounded, 13-24 $\mathrm{mm}$ long, 8-20 $\mathrm{mm}$ wide, pubescent, yellow when mature; seeds angular, 2-3 mm long, 220-234 per fruit.

Selected specimens: Alfredo Chaves, 8.V.1985, fr., $G$. Martinelli 10895 (RB). Aracruz, 11.IX.1993, fl., M. Simonelli (VIES 7454). Castelo 8.IV.2009, fr., C.N. Fraga 2465 (MBML, RB). Conceição da Barra, 24.I.2012, fr., A. Giaretta 1171 (RB). Fundão, 22.IV.1984, W. Pizziolo 96 (MBML). Guarapari, 18.V.2000, fr., J.R. Pirani 4726 (RB). Linhares, 18.II.1997, fr., R.L.S. Dutra 244 (VIES). Marataízes, 3.XI.1972, fr., L. Krieger 11872 (RB). Muniz Freire, 15.V.2009, fr., C.C. Jorden Almaça (RB 494178). Santa Leopoldina, 1.V.2006, fr., M.O.S. Crepaldi 125 (RB). Santa Maria de Jetibá, 11.I.2008, fl. and fr., T.S.
Lorencini 17 (VIES). Santa Teresa, 28.V.2002, fr., R.R. Vervloet 317 (MBML, VIES). São Mateus, 2.II.2012, fl. and fr., A. Giaretta 1223 (RB). Serra, 22.IV.1993, fl., O.J. Pereira 4525 (VIES). Vila Velha, 6.XII.1997, fr., J.M.L. Gomes 2238 (VIES). Vitória, 1.X.1998, fl., A.M. Assis 652 (VIES).

Psidium guineense can be recognized by the elliptic leaf-blade with 6-12 pairs of secondary veins, and rounded and pubescent fruits. This species resembles $P$. guajava in the quadrangular branches, elliptic leaf-blade and leaf size. However, $P$. guajava has $12-18$ pairs of secondary veins, and glabrous leaves and fruits. Psidium guineense occurs from Mexico and the Caribbean to Argentina. The species is widely distributed in Brazil, occurring in the Amazon Rainforest, Cerrado and Atlantic Rainforest (BFG 2015), where is known in almost all states. In the state of Espírito Santo, Psidium guineense is a common and widely distributed species, occurring within protected areas (Itaúnas State Park, Paulo Cézar Vinha State Park, Santa Lúcia Biological Station, Vale Natural Reserve). Occurs in tabuleiro, montane and resting a vegetation and is commonly found in disturbed areas (Fig. 5b). It was collected in flowers between October and May and fruiting between January and March.

6. Psidium longipetiolatum D.Legrand Sellowia, 13: 341, $1961 . \quad$ Figs. 3g-j; 5b

Tree, 14-30 m tall; glabrous or glabrescent, branches cylindrical, 1.5-6 $\mathrm{mm}$ diam., petiole 10-25 × 1-1.5 mm, leaf-blade obovate, rare elliptic $6-12 \times 2.3-5.5 \mathrm{~cm}$, chartaceous or coriaceous, glabrous, apex acuminate, acute or obtuse rounded, base cuneate or obtuse, margin entire, slightly revolute; midvein slightly sulcate above and prominent below; 8-10 pair of secondary veins, inconspicuous in the adaxial face, evident in the abaxial face, brochidodromous, marginal vein 1-3 $\mathrm{mm}$ from the margin. Solitary flower; pedicels $7-30 \times 0.7-1.5 \mathrm{~mm}$; bracts $2-2.5 \times 2.5-3 \mathrm{~mm}$, ovate, caduceus; bracteoles $0.2-0.3 \times 0.4-0.5 \mathrm{~mm}$, persistent. Floral buds 13-15 $\times 7-11 \mathrm{~mm}$, pyriform, calyx with lobes entirely fused, tearing at anthesis in 4-5 lobed, sepals 2-3 $2-3 \mathrm{~mm}$, equal in size. Flowers not seen. Ovary 4-5 locular, $8-10$ ovules per locule. Fruits rounded, 13-20 × 10-17 mm, glabrous, yellow or red when mature; seeds angular, 4-6 mm long, 11-14 per fruit.

Selected specimens: Linhares, 10.II.2007, fr., D.A. Folli 5197 (CVRD).

Additional specimen examined: Nova Friburgo, 3.XI.2013, fr., P.V. Pietro (RB 843286). 

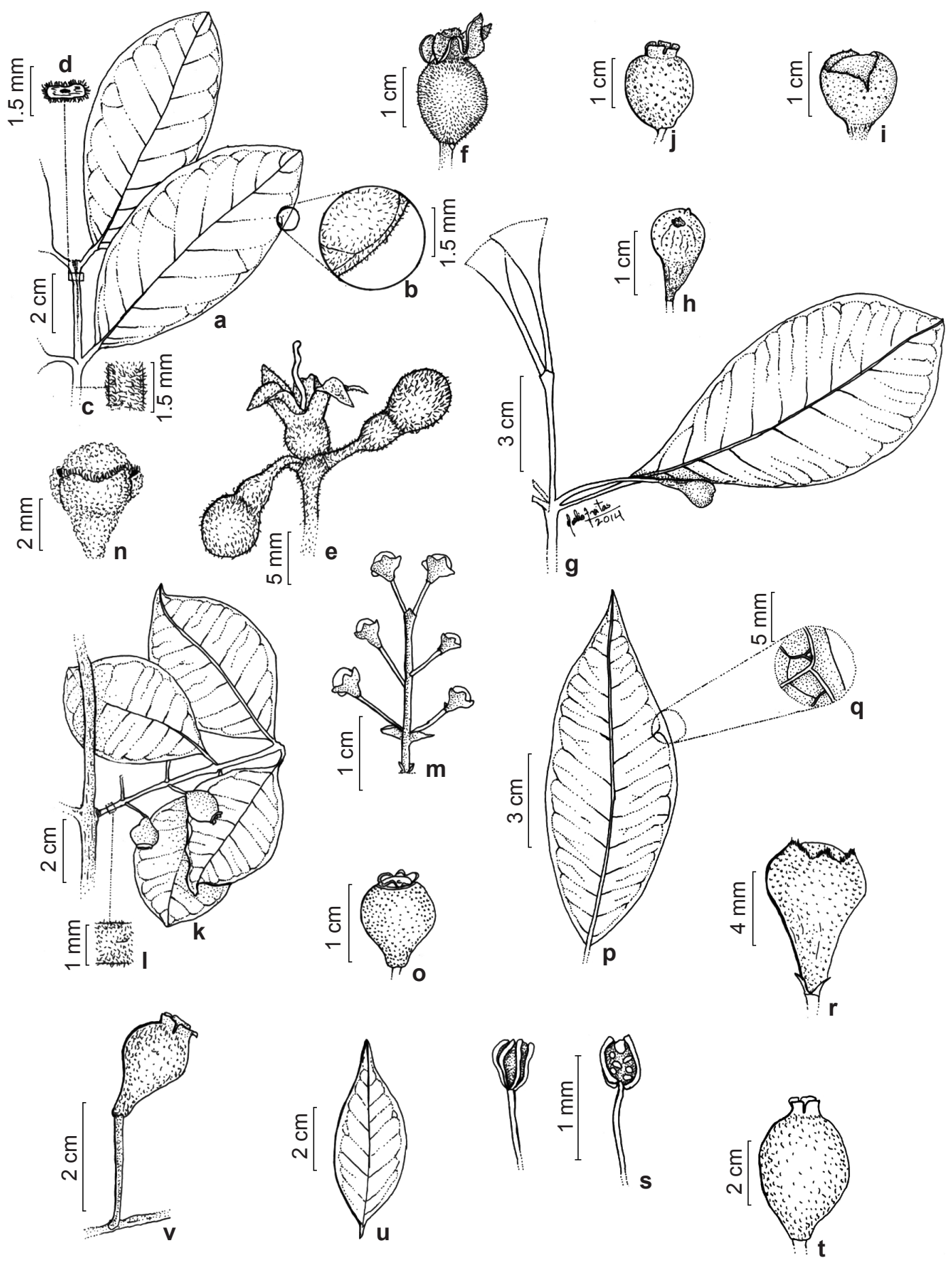

Figure 3 - a-f. Psidium guineense - a. elliptic leaves; b,c. leaves and branches sparsely pubescent; d. tetragonal branches; e. dichasia; f. pubescent and globose fruit. g-j. Psidium longipetiolatum - g. obovate leaves and axillary, uniflorous inflorescences; h,i. pyriform, apiculated floral buds; j. rounded fruits. k-o. Psidium myrtoides - k. elliptic leaves; 1. glabrescent branches; $\mathrm{m}$. raceme; n. calyx partially fused; o. pyriform fruits. p-t. Psidium oblongatum - p. elliptic or oblong leaves; q. secondary veins evident on both sides; r. pyriform, partially fused floral buds; s. anthers globose with apical glands; t. pyriform fruit. u,v. Psidium oligospermum - u. elliptic leaves, apex acuminate; v. pyriform fruit. (a,f. V.C. Manhães 459; g,i. P.V. Pietro sn.(RB 843286); j. D.A. Folli 5197; k,n. A.C. Tuler 451; o. A.C. Tuler 510; p,q. V. Demuner 4594; r,t. T.T. Carrijo 2105; u,v. L.A. Silva 106). 
Psidium longipetiolatum resembles $P$. cattleianum in the obovate leaf-blade and rounded fruits, however it differs mainly by the longer petiole and pedicels, and by fused calyx lobes. In the field, the bark of this species is remarkably smooth and reddish in colour. Endemic to the Atlantic Rainforest, $P$. longipetiolatum occurs in the states of Rio de Janeiro, São Paulo, Paraná, Rio Grande do Sul and Santa Catarina (Legrand \& Klein 1977; BFG 2015). In Espírito Santo this species is known from tabuleiro forest in the Vale Natural Reserve (Fig. 5b). It was collected in fruit in February and March.

7. Psidium myrtoides O.Berg, Fl. bras. 14 (1): 384, 1857.

Figs. 3k-o; 5c

Tree or shrub, 3-20 m tall; glabrous or glabrescent, branches cylindrical, $0.8-3.5 \mathrm{~mm}$ diam.; petiole 4-7 $\times 0.5-1.5 \mathrm{~mm}$, leaf-blade elliptic or obovate, $2.5-11 \times 1-4.5 \mathrm{~cm}$, chartaceous or coriaceous, sparsely pubescent so along midvein, apex acuminate, acute or obtuse, base cuneate or acute, margin entire, slightly revolute.; midvein slightly sulcate above and prominent below; 7-14 pairs of secondary veins, evident on both sides, brochidodromous, marginal vein 1-2 $\mathrm{mm}$ from the margin. Inflorescence growing from terminal raceme or lateral or auxotelic axis producing vegetative shoots with adult leaves after anthesis, 1-8 flowered; pedicels 3-12 mm long; bracts ovate or triangular 2-3 $\times 1.5-2 \mathrm{~mm}$, caducous; bracteoles $0.5-1 \times 0.2-1 \mathrm{~mm}$. Floral buds $2-6 \times 2.3-4 \mathrm{~mm}$, pyriform, calyx partially fused, tearing in five lobes, sepals $0.8-2 \times 1-3 \mathrm{~mm}$, rounded, equal in size; petals $4-5 \times 3-5 \mathrm{~mm}$, white; stamens 3-6 $\mathrm{mm}$, anthers globose, $0.5-1 \mathrm{~mm}$ long, rimose; ovary 4-locular 5-8 ovules per locule. Fruits pyriform or rounded, 9-16 mm long, 5.5-14 mm wide, glabrous, red when mature; seeds angular, 4-5 mm long, 4-10 per fruit.

Selected specimens: Cariacica, 20.VII.2008, fr., A.M.A. Amorim 7576 (RB). Conceição da Barra, 24.X.2012, fr., A. Giaretta 1350 (RB). Domingos Martins,15.III.2001, fr., O.J. Pereira, 6920 (VIES). Fundão, 18.III.2005, fr., L. Kollmann 7459 (MBML). Itapemirim, VII.2003, fr., A.L. Ferreira (VIES). Itarana, 14.II.1999, fr., E.M. Nic Lughadha (MBML, VIES). Linhares, 10.V.2000, fr., D.A. Folli 3617 (CVRD). Marechal Floriano 4.IV.2008, fr., J.W. Calatrone 69 (VIES). Pancas, 23.III.2007, fr., A.A. Luz 382 (CVRD). Santa Leopoldina, 23.X.2007, fl., V. Demuner 4293 (MBML, VIES). Santa Teresa, 13.V.2005, fr., L. Kollmann 7766 (MBML, VIES). Serra, 23.XII.2010, fr., R.M. Botelho 99 (MBML). Vitória, 10.X.1990, fr., M.L.L. Martins 23 (VIES).
Psidium myrtoides can be distinguished by the elliptic leaf-blade and fruits with rounded, persistent sepals. This species resembles $P$. brownianum by leaf size and shape, but differs by the pyriform or rounded fruits with rounded and persistent sepals. Endemic to Brazil, P. myrtoides occurs in the states of Tocantins, Bahia, Ceará, Maranhão, Distrito Federal, Goiás, Espírito Santo, Minas Gerais, Rio de Janeiro, São Paulo, Paraná and Rio Grande do Sul, in Caatinga, Cerrado and Atlantic Rainforest (BFG 2015). In the state of Espírito Santo, this species is known by the common name "araçaúna", and is widely distributed, occurring in tabuleiro, montane and restinga vegetation, including protected areas (Fig. 5c). It was collected in flower between April and December, and fruits between February and December.

8. Psidium oblongatum O. Berg, Fl. bras. 14(1): 392. 1857.

Figs. 3p-t; $5 \mathrm{c}$

Tree or shrub, 4-12 m tall; glabrous, branches cylindrical, 1.5-4 mm diam., petiole 4-10 $\times 0.9-2.5$ $\mathrm{mm}$, leaf-blade elliptic or oblong, $6.8-19 \times 2.7-7.8$ $\mathrm{cm}$, chartaceous or coriaceous, apex acuminate, base cuneate or attenuate, margin entire, slightly revolute; midvein impressed or slightly sulcate above, prominent bellow; 10-16 pairs of secondary veins, evident on both sides, marginal vein 1-4 $\mathrm{mm}$ from the margin. Inflorescence growing from terminal raceme or lateral, 1-8 flowered; pedicels 3-6 mm long, $0.4-1 \mathrm{~mm}$ wide; bracts ovate or lineate $1 \times 0.5 \mathrm{~mm}$, caducous; bracteoles ovate or lineate $0.6-1 \times 0.3-1 \mathrm{~mm}$. Floral buds $7-10 \times 6-7$ $\mathrm{mm}$, pyriform, calyx partially fused, $4-5$ lobed, sepals $4-7 \times 3-5 \mathrm{~mm}$, quadrangular, equal in size; petals $4-7 \times 3-5 \mathrm{~mm}$, white; stamens $3-5 \mathrm{~mm}$, anthers globose $0.6-1 \mathrm{~mm}$ long, rimose, with apical glands; ovary 4-locular, 6-10 ovules per locule. Fruits pyriform or rounded, $38-53 \times 26-56.5 \mathrm{~mm}$, glabrous, yellow when mature; seeds rounded, 7-9 mm long, 15-20 per fruit.

Selected specimens: Águia Branca, 1.II.2006, fl., L.F.S. Magnago 555 (MBML). Cariacica, 22.VII.2008, fr., C.N. Fraga 2177 (RB). Governador Lindemberg, 23.VIII.2006, fr., V. Demuner et al. 2732 (MBML, VIES). Linhares, 16.XII.2003, fl., D.A. Folli 4708 (CVRD). Santa Leopoldina, 30.XII.2007, fl., V. Demuner 4647 (MBML). Santa Teresa, 11.III.1999, fr., L. Kollmann 2139 (MBML, RB).

Psidium oblongatum can be recognized by the elliptic or oblong leaf-blade with clearly marked secondary veins on both sides, fruits with rounded seeds, and globose anthers with apical 
glands. The shape and size of fruits resemble those of $P$. guajava. However, P. oblongatum differs by the floral buds partially fused, regular sepals, and 15-20 rounded seeds per fruit. This species is restricted to the Atlantic Rainforest areas of Espírito Santo and Minas Gerais states (BFG 2015). In Espírito Santo, populations with few, scattered individuals were found both in montane and tabuleiro forests (Fig. 5c). It was collected in flowers between October and February and fruiting between December and July.

9. Psidium oligospermum Mart. ex DC. Prodr., 3: 236. 1828.

Figs. $3 \mathrm{u}, \mathrm{v} ; 5 \mathrm{c}$

Shrub $1 \mathrm{~m}$ tall; glabrescent, branches cylindrical, $1-2 \mathrm{~mm}$ diam., petiole $2-4 \times 0.6-0.7$ $\mathrm{mm}$, leaf-blade elliptic, $3.3-6.5 \times 1.2-2.2 \mathrm{~cm}$, chartaceous, sparsely pubescent so along midvein, apex acuminate, base acute or cuneate; margin entire, slightly revolute; midvein slightly sulcate above and prominent below; $6-8$ pairs of secondary veins, evident on both sides, brochidodromous, marginal vein $1-1.5 \mathrm{~mm}$ from the margin. Solitary flower; pedicels $12-17 \times 0.2-0.5 \mathrm{~mm}$; bracts and bracteoles not seen. Floral buds $4-6 \times 3.5-4 \mathrm{~mm}$, pyriform, calyx with lobes entirely fused, tearing irregularly as a calyptra; petals $5 \times 4 \mathrm{~mm}$, white; stamens 4-6 mm, anthers globose, $1 \mathrm{~mm}$ long, rimose; ovary 3-locular, 8-12 ovules per locule. Fruits pyriform or rounded, 16-21 × 6-12 mm, glabrous, yellow when mature; seeds angular, $3-4$ $\mathrm{mm}$ long, 5 per fruit.

Selected specimens: Santa Teresa, 10.II.1999, fr., $L$. Kollmann 1913 (MBML). Vila Velha, 8.II.2012, fr., $L$. A. Silva 106 (VIES).

Additional specimen examined: BRAZIL. BAHIA: Esplanada, 29.V.1996, fl., T. Jost \& M.C. Ferreira 306 (RB).

Psidium oligospermum can be distinguished by its shrubby habit and rounded or pyriform yellow fruits. This species resembles $P$. sartorianum in leaf size and shape, differing by its shrubby habit and yellow fruits. Native to Brazil, P. oligospermum occurs in the states of Alagoas, Bahia, Ceará, Maranhão, Paraíba, Pernambuco, Piauí, Rio Grande do Norte, Sergipe, Goiás, Espírito Santo and Minas Gerais, in Caatinga, Cerrado, and Atlantic Rainforest (BFG 2015). Although it is common in the Northeast of Brazil, in the state of Espírito Santo the species has so far been found only in the localities of Santa Teresa, outside the protected areas, and at Vila Velha, within the Municipal Park of Jacarenema (Fig. 5c). It was collected in fruit in February and March.
10. Psidium ovale (Spreng.) Burret, Notizbl. Königl. Bot. Gart. Berlin, 15: 485. 1941.

Figs. 4a-e; 5d

Shrub 1-2 m tall; glabrescent, cylindrical branches, $0.7-3 \mathrm{~mm}$ diam., petiole $1-2 \times 0.7-1$ $\mathrm{mm}$, pubescent; leaf-blade ovate or elliptic $1-3.5$ $\times 0.5-2 \mathrm{~cm}$, chartaceous, sparsely pubescent so along midvein, apex obtuse or rounded, base acute or attenuate, margin entire, revolute; midvein slightly sulcate above and prominent below; $6-10$ pairs of secondary veins, evident on both sides, brochidodromous, marginal vein $0.5-1 \mathrm{~mm}$ from the margin. Inflorescence growing from terminal raceme, solitary flower or auxotelic axis producing vegetative shoots with adult leaves after anthesis, 1-6 flowered; pedicels $2-8 \times 0.2-0.5 \mathrm{~mm}$; bracts triangular, ovate or lineate $0.5-2 \times 0.3-1 \mathrm{~mm}$, bracteoles ovate or lineate $0.4-1.5 \times 0.2-0.5 \mathrm{~mm}$, pubescent. Floral buds $1.5-3 \times 1-2 \mathrm{~mm}$, pyriform, calyx partially fused, tearing in five lobes, sepals $0.2-1 \times 1-1.5 \mathrm{~mm}$, rounded, equal in size, puberulent; petals 4-mera 3-3.2 $\times 1.5-2 \mathrm{~mm}$, white; free, stamens $1.5-2 \mathrm{~mm}$ long, anthers globose, $0.3-0.6 \mathrm{~mm}$ long, rimose; ovary $2-3$ locular, $2-4$ ovules per locule. Fruits rounded, 4.8-5 × 4.5-5 $\mathrm{mm}$, glabrous, yellow when mature; seeds angular, 4-5 mm long, 4 per fruit.

Selected specimens: Santa Leopoldina, 18.V.2011, fl., J.E.Q. Faria 1218 (UB). Santa Teresa, 6.VI.1990, fl., M. Gibran 123 (RB, CVRD). São Roque do Canaã, 14.XI.2004, fl., A.P. Fontana et al. 1050 (MBML, VIES).

Psidium ovale can be recognized by the ovate or elliptic leaf-blade and small and rounded fruits. This species resembles $P$. oligospermum due to its similar leaves, but differs by presenting smaller and rounded fruits. Endemic to the Atlantic Rainforest, P. ovale occurs in the states of Minas Gerais, São Paulo, Espírito Santo, Paraná and Santa Catarina (BFG 2015). In Espírito Santo, populations of few and scattered individuals of this species grow in montane forest within conservation areas (Fig. 5d). It was collected flowering between June and November, and fruiting in April.

11. Psidium rhombeum O. Berg, Fl. bras., 14(1): $383,1857$.

Figs. 3f; $5 \mathrm{~d}$

Tree, $8 \mathrm{~m}$ tall; albo-pubescent, cylindrical branches $1-3 \mathrm{~mm}$ diam.; petiole $4-5 \times 0.8-1$ $\mathrm{mm}$, leaf-blade rhomboid, $6.3-7 \times 3.1-3.5 \mathrm{~cm}$, chartaceous, glabrescent, apex acuminate, base acute or cuneate; midvein slightly sulcate above and prominent below; 8-10 pairs of secondary veins, evident on both sides, brochidodromous, 

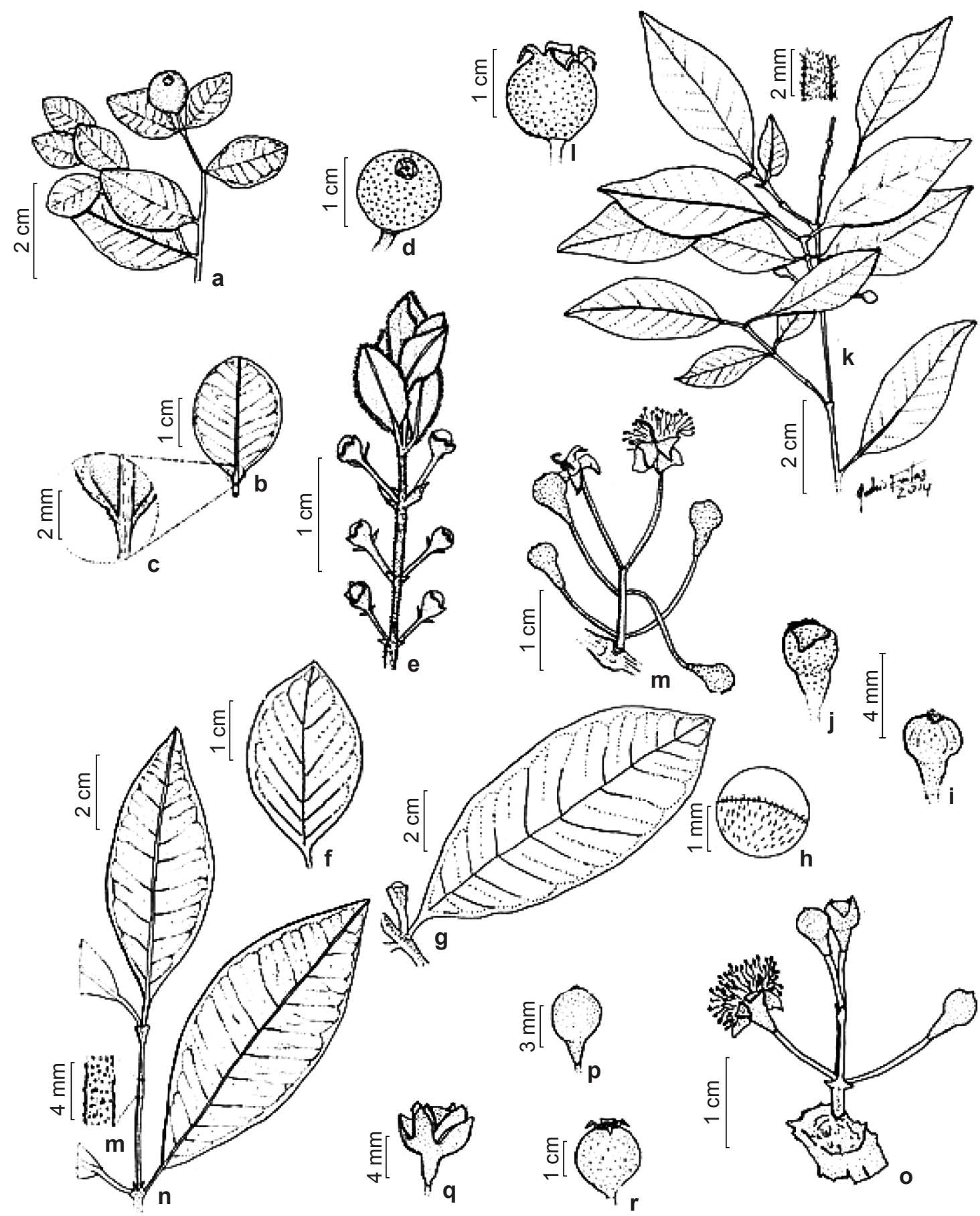

Figure 4-a-e. Psidium ovale - a. branches; b,c. ovate leaves, sparsely pubescent; d. globose fruits; e. axillary inflorescences, with continuing vegetative growth. f. Psidium rhombeum - rhomboid leaves. g-i. Psidium rufum - g. elliptic leaves; h. densely pubescente; i. pyriform, partially fused floral buds. j-m. Psidium sartorianum - j. floral buds; $\mathrm{k}$. sparsely pubescent raceme; 1. globose fruits; m. pyriform floral buds. n-r. Psidium sp. - n. glabrous branches; o. flowers on the trunk; p. pyriform, entirely fused, apiculate q. calyx 4-5-lobed; r. glabrous,rounded fruit. (a,c. A.P. Fontana 1050; d,e. V. Demuner 920; f. E.M. Nic Lughadha 201; g,i. M.M. Arbo 7724; j,1. D.A. Folli 376; m. I.A. Silva 279; n,o. M. Ribeiro 811; p,r. A.C. Tuler 496). 
marginal vein $1 \mathrm{~mm}$ from the margin, margin entire, slightly revolute. Solitary flower or auxotelic axis producing vegetative shoots with adult leaves after anthesis, 1-8 flowered; pedicels 7-10 $\times 0.2$ $\mathrm{mm}$;bracts rounded $1 \times 1 \mathrm{~mm}$, bracteoles lineate $0.3-0.5 \times 0.1 \mathrm{~mm}$. Floral buds $3 \times 4 \mathrm{~mm}$, pyriform, calyx partially fused, tearing in five lobes, sepals 1-2 × 1-1.5 mm, stamens 4-5 mm long, anthers globose, 0.8-1 mm long, rimose; ovary 2-locular, 3-4 ovules per locule. Fruits pyriform, 10-13 $\times$ 6.8-9 mm, 5-sepals, 1.5-2 mm, glabrescent; seeds 4-5 per fruit, 5-7 $\mathrm{mm}$ long, angular.

Selected specimens: Itarana, 14.II.1999, E.M. Nic Lughadha 201 (JBRJ, MBML, VIES). Marechal Floriano, 21.X.2000, G. Hatschbach 71498 (CEPEC).

Psidium rhombeum can be distinguisehd by the rhomboid and glabrescent leaf-blade. This species resembles $P$. myrtoides in fruit size and shape, but differs by its rhomboid leaf-blade. Psidium rhombeum was previously known only from the Atlantic Rainforest of Bahia (BFG 2015). The specimen identification of $G$. Hatschbach 71498 from Marechal Floriano and E.M. Nic Lughadha 201 from Itarana expanded the geographic distribution of this species into Espírito Santo, where the species also occurs in montane forest (Fig. 5d). It was collected with fruits in February.

12. Psidium rufum Mart. ex DC., Prodr. 3: 234, 1828.

Figs. 3g-i; 5d

Tree 3-4 m tall; branches densely pubescent, hairs rusty brown to reddish, tetragonal; petiole 1.5-2 mm diâm.; petiole 4-6 × 0.5-1 mm, leafblade elliptic, 6-14 × 2.5-6 cm, chartaceous or coriaceous, sparsely pubescent, more densely so along midvein and leaf margin, apex acute, base cuneate or acute, margin entire, slightly revolute; midvein slightly sulcate above and prominent below; 10-12 pairs of secondary veins, evident on both faces, brochidodromous, marginal vein 1-2 $\mathrm{mm}$ from the margin. Solitary flower; pedicels $3-5 \times 0.3-0.5 \mathrm{~mm}$; bracts ovate $1-3 \times 0.5-1 \mathrm{~mm}$, bracteoles ovate or linear, 2-3 $\times 1-2 \mathrm{~mm}$. Floral buds 5-8 $\times 4-5 \mathrm{~mm}$, pyriform, calyx partially fused, tearing in five lobes, sepals $4-5 \times 2-3 \mathrm{~mm}$, irregular size and shape, puberulent; flowers not seen. Ovary 3-locular, 5 ovules per locule. Fruits rounded, 30-42 × 15-23 mm wide, pubescent; seeds angular, 3-4 mm long, 10 per fruit.

Selected specimens: Venda Nova do Imigrante, 27.I.1997, fl., M.M. Arbo 7724 (RB). Santa Teresa, 18.I.1995, fr., L.D. Thomaz 1073 (MBML, RB)
Additional specimen examined: BRAZIL. MINAS GERAIS: Descoberto, Reserva Biológica da Represa do Grama 18.V.2002, fr., A.V. Lopes 36 (RB).

Psidium rufum can be recognized mainly by having branches, leaves and fruits covered with densely ferrugineous to reddish indumentums, otherwise resembling $P$. oblongatum in leaf-blade size and shape. Native to Brazil, it occurs in the states of Bahia, Ceará, Goiás, Distrito Federal, Espírito Santo, Minas Gerais, Rio de Janeiro, São Paulo and Paraná in Cerrado and Atlantic Rainforest (BFG 2015). In the state of Espírito Santo, the species is only known so far from two collections from Venda Nova do Imigrante and Santa Teresa, both on montane forest and not known inside protected areas (Fig. 5d). It was collected in flowers in January and fruiting in April.

13. Psidium sartorianum (O. Berg) Nied., Nat. Pflanzenfam. 3(7): 69, $1893 . \quad$ Figs. 4i-m; 5d

Tree 20-28 m tall; glabrescent, cylindrical branches, 1-3.2 $\mathrm{mm}$ diam., petiole 1.5-4 $\times$ 0.3-1 mm, leaf-blade elliptic 2.1-5.8 × 0.8-2.2 $\mathrm{cm}$, chartaceous, discolorous when dry, sparsely pubescent so along midvein, apex acute or acuminate, base acute or cuneate, margin entire, revolute; midvein slightly sulcate above and prominent below; 8-10 pairs of secondary veins, evident on both sides, brochidodromous, marginal vein $0.5-1 \mathrm{~mm}$ from the margin. Solitary flower or raceme 1-8 flowered; pedicels 6-15 × 0.2-0.5 mm; bracts ovate or triangular $1 \times 0.5 \mathrm{~mm}$, bracteoles ovate or lineate $0.3-0.4 \times 0.2 \mathrm{~mm}$. Floral buds 3-5 $\times 2-3 \mathrm{~mm}$, pyriform, calyx with lobes entirely fused tearing at anthesis in four or five lobes, sepals 1.5-3 $\times 2-3 \mathrm{~mm}$, irregular size and shape; petals 3-4 $\times 2.5-3 \mathrm{~mm}$, white; stamens 3-5 mm, anthers globose, $0.8 \times 0.4 \mathrm{~mm}$, rimose; ovary 3-locular, 6-8 ovules per locule. Fruits rounded, 11-15 × 9-14 $\mathrm{mm}$, glabrous, striated fruits, red when mature; seeds 9-10 per fruit 4-5 mm long, rounded.

Selected specimen: Linhares, 9.XII.1981, fl. and fr., D.A. Folli 376 (CVRD, BHCB).

Psidium sartorianum can be recognized by their habit and red, rounded fruits. This species resembles $P$. oligospermum by its elliptic leafblade; however it differs in habit and calyx tearing at anthesis in four or five lobes. $P$. sartorianum is known by the common name of "araçá-gigante". Native to Brazil, the species occurs in the states of Acre, Rondônia, Bahia, Goiás, Mato-Grosso, Espírito Santo, Minas Gerais, São Paulo and Paraná (BFG 2015). In the state of Espírito Santo, 

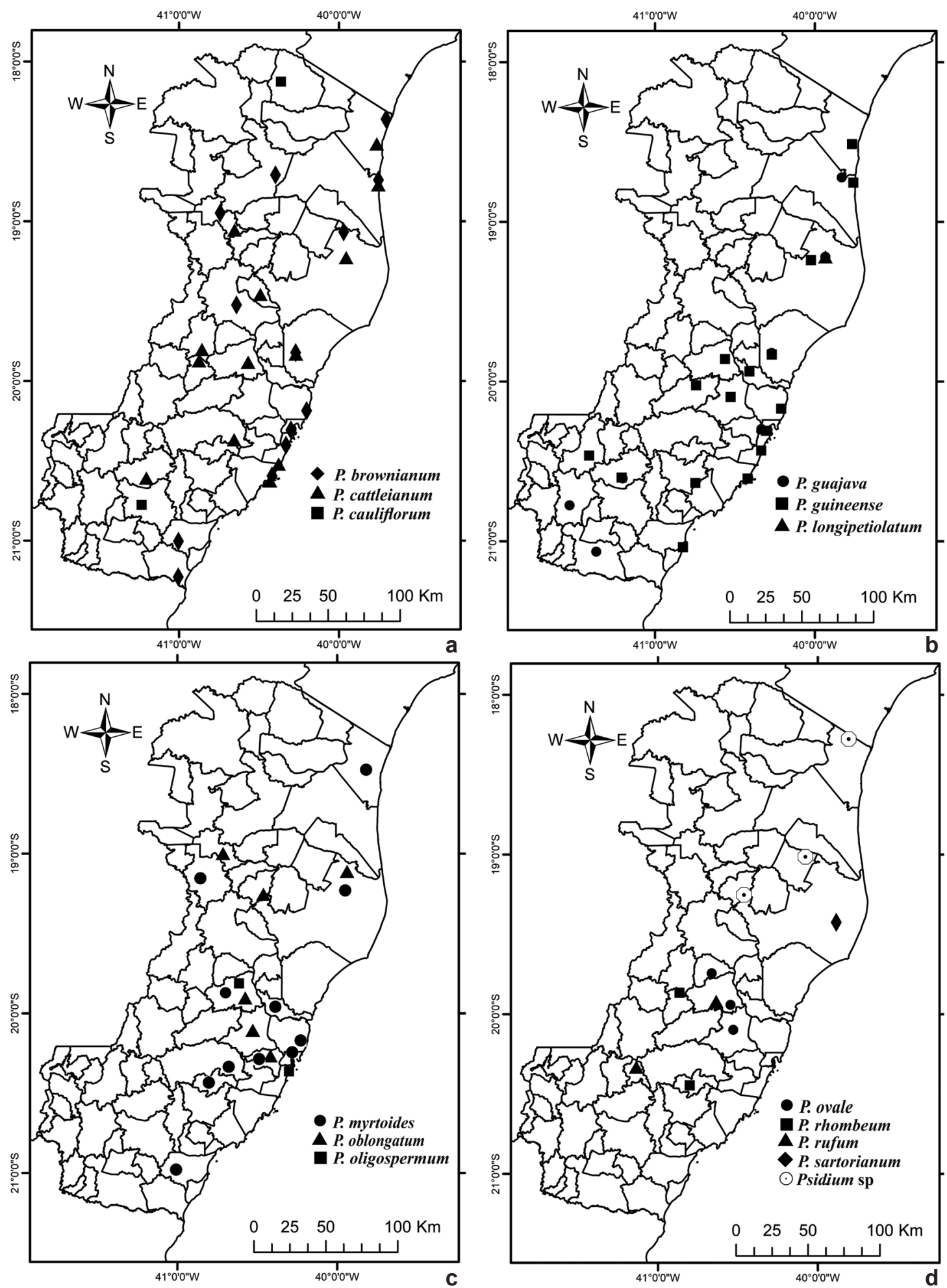

Figure 5 - Geographic distribution of Psidium species in the state of Espírito Santo: a. P. brownianum, $P$. cattleianum, $P$. cauliflorum. b. P. guajava, $P$. guineense and $P$. longipetiolatum. c. P. myrtoides, $P$. oblongatum and $P$. oligospermum. d. $P$. ovale, $P$. rhombeum, $P$. rufum, $P$. sartorianum and Psidium sp. 
P. sartorianum is known by few collections from the Vale Natural Reserve, in tabuleiro forest (Fig. 5d). It was collected in flower in December and fruiting between December and March.

\section{Psidium sp.}

Figs. 4n-r; 5d

Tree 6-12 m tall, glabrous, cylindrical branches, $1-3 \mathrm{~mm}$ diam., petiole $3-7 \times 0.5-1.2$ $\mathrm{mm}$, leaf-blade elliptic, $4.5-11.5 \times 2-4.7 \mathrm{~cm}$, chartaceous, discolorous when dry, sparsely pubescent, apex acuminate or acute, base cuneate, margin entire, slightly revolute, repined; midvein slightly sulcate above and prominent below; $12-14$ pairs of secondary veins, evident on both sides, brochidodromous, marginal vein $1-2 \mathrm{~mm}$ from the margin. Inflorescence borne in clusters on older branches or trunk, or dichasia botryoid, or raceme $1-8$ flowered; pedicels $7-18 \times 0.1-0.5 \mathrm{~mm}$, redish; bracts ovate or triangular $1-1.5 \times 0.5-0.8 \mathrm{~mm}$; lineate bracteoles $0.5-1 \times 0.2-0,5 \mathrm{~mm}$. Floral buds 4-7 $\times 3-4.5 \mathrm{~mm}$, pyriform, apiculated, sparsely pubescent, calyx with lobes entirely fused tearing at anthesis in 4-5 lobes, sepals 3-5 $\times 2-4 \mathrm{~mm}$, rounded or triangular, pubescent; petals 4-5 $\times 4-5.5$ $\mathrm{mm}$, white; stamens $5-7 \mathrm{~mm}$, anthers globose $0.3-$ $0.5 \times 0.2-0.4 \mathrm{~mm}$, rimose; ovary 3-locular, ovules 7-12 per locule. Fruits rounded or slightly pyriform 11-25 × 10-20 mm, glabrous, wine-coloured when mature; seeds 6-8 per fruit 4-5 $\mathrm{mm}$ long, angular. Selected specimens: Conceição da Barra, 14.I.2014, fl. and fr., A.C. Tuler et al. 496 (RB). Governador Lindemberg, J.E.Q. Faria 2535. Sooretama, 18.I.2010, fr., M.F. Gusson 04 (VIES).

Psidium sp. can be recognized by the clusters of flowers attached to the trunk or to older branches and glabrous, wine-colored fruits. This species resembles $P$. cauliflorum due the cauliflorous inflorescence and by the elliptic leaf-blade, but differs by the absence of trichomes in flowers and fruits, and its apiculate floral buds. So far found only in the Atlantic Rainforest, there are records of similar materials in Espírito Santo and Rio de Janeiro (I.G. Costa, 359). In the state of Espírito Santo, Psidium sp. is known by populations of few scattered individuals occurring in tabuleiro forest at Sooretama Biological Reserve and Córrego Grande Biological Reserve (Fig. 5d). It was collected in flower between December and January and fruiting between January and April.

\section{Acknowledgements}

We thank CAPES for financial support provided to the first author; to the Universidade
Federal do Espírito Santo (UFES) for the support during the project; to FAPES for supporting the project "Diversity of genus Psidium in the state of Espírito Santo". We also thank RB, VIES, MBML and CVRD herbaria for loaning material, Marcos Sobral, Daniela Zappi, and an anonymous reviewer for helpful comments on the manuscript, Geovane Siqueira and Vitor Manhães for the assistance during the fieldwork; to Dalvan Ribeiro de Almeida for preparing the map and to Joélcio Freitas for the botanical illustration.

\section{References}

Antongiovanni LL \& Coelho ALN (2005) Panorama sobre a desertificação no estado do Espírito Santo. Consultoria e relatório apresentados para o IEMA do Governo do Estado do Espírito Santo. Pp. 1-87.

BFG - The Brazil Flora Group (2015) Growing knowledge: an overview of seed plant diversity in Brazil. Rodriguésia 66: 1085-1113.

Barroso GM \& Peixoto AL (1995) Myrtaceae da Reserva Florestal de Linhares, ES, Brasil - gêneros Calyptranthes e Marlierea. Boletim do Museu de Biologia Mello Leitão 3: 3-38.

Barroso GM \& Peron M (1994) Myrtaceae. In: Lima MPM \& Guedes-Bruni RR (orgs.) Reserva Ecológica de Macaé de Cima, Nova Friburgo, RJ: aspectos florísticos das espécies vasculares. Jardim Botânico do Rio de Janeiro, Rio de Janeiro. Pp. 261-296.

Berg O (1857-1859) Myrtaceae. In: Martius CFP (ed.) Flora brasiliensis. R Oldenbourg, Munich, Leipzig. Vol. 14, pars 1, pp. 1-656.

Candolle AP (1828) Myrtaceae. In: de Candolle AP (ed.) Prodromus systematis naturalis regni vegetabilis 3: 207-296.

Dutra VF, Alves-Araújo A \& Carrijo TT (2015) Angiosperm checklist of Espírito Santo: using electronic tools to improve the knowledge of an Atlantic Forest biodiversity hotspot. Rodriguésia 66: 1145-1152. DOI: 10.1590/2175-7860201566414

Funch LS, Landrum LL, Oliveira MIU, Proença CEB, Mazine FF \& Rosário AS (2009) Myrtaceae In: Giuliette AM, Rapini A, Andrade MJG, Queiroz LG \& Silva JMC. Plantas raras do Brasil. Conservação Internacional, Belo Horizonte; Universidade Estadual de Feira de Santana, Feira de Santana. Pp. 289-292.

Giaretta A, Menezes LFT \& Peixoto AL (2015) Diversity of Myrtaceae in the southeastern Atlantic forest of Brazil as a tool for conservation. Brazilian Journal of Botany: 38: 175-185. DOI:10.1007/s40415014-0121-y

Giaretta A \& Peixoto AL (2015) Myrtaceae da restinga no norte do Espírito Santo, Brasil. Boletim do Museu de Biologia Mello Leitão 37: 45-126. 
Hickey M \& King C (2000) The Cambridge illustrated glossary of botanical terms. Cambridge University Press, Cambridge. 209p.

Hijmans RJ, Guarino L, Jarvis A, O'Brien R, Mathur P, Bussink C, Cruz M, Barrantes I \& Rojas E (2005) DIVA-GIS version 5.2. Biodiversity International, Rome. Availabe at $<\mathrm{http}$ ://www.diva-gis.org/>.

IUCN - International Union for Conservation of Nature (2014) The IUCN Red List of Threatened Species. Version 2014.3. Availabe at $<$ http://www.iucnredlist. org $>$. Access on 17 February 2014.

Jesus RM \& Rolim SG (2005) Fitossociologia da Mata Atlântica de Tabuleiro. Boletim Técnico da Sociedade de Investigações Florestais 19: 1-149.

Kawasaki ML (1989) Flora da Serra do Cipó, MG, Brasil: Myrtaceae. Boletim de Botânica da Universidade de São Paulo 11: 121-170.

Landrum LR \& Kawasaki ML (1997) The genera of Myrtaceae in Brasil: an illustrated synoptic treatment and identification keys. Brittonia 49: 508-536.

Landrum LR \& Sharp WP (1989) Seed coat characters of some American Myrtinae (Myrtaceae): Psidium and related genera. Systematic Botany 14: 370-376.

Landrum LR \& Sobral M (2006) Psidium cauliflorum (Myrtaceae), a new species from Bahia, Brazil. SIDA, Contributions to Botany 22: 927-929.

Legrand CD \& Klein RM (1977) Myrtáceas: 8. Campomanesia, 9. Feijoa, 10. Britoa, 11. Myrrhinium, 12. Hexachlamys, 13. Siphoneugena, 14. Myrcianthes, 15. Neomitranthes, 16. Psidium. In: Reitz R (org.) Flora Ilustrada Catarinense: 570-730.

Mazine FF \& Souza VC (2007) Myrtaceae dos campos de altitude do Parque Nacional do Caparaó - Espírito Santo / Minas Gerais, Brasil. Rodriguésia 59: 57-74.

Morais PO \& Lombardi JA (2006) A família Myrtaceae na Reserva Particular do Patrimônio Natural da Serra do Caraça, Catas Altas, Minas Gerais, Brasil. Lundiana 7: 3-32.

McVaugh R (1958) Flora of Peru: Myrtaceae. Field Museum of Natural History 13: 569-818.

McVaugh R (1963) Flora of Guatemala: Myrtaceae. Fieldiana 24: 285-403.

McVaugh R (1968) The genera of American Myrtaceae - an interim report. Taxon 17: 354-418.

Niedenzu F (1893) Myrtaceae. In: Engler A \& Prantl K. Die natürlichen Pflanzenfamilien 3: 57-105.
Paula A (2006) Os estados da Mata Atlântica: Espírito Santo. In: Campanili M \& Prochnowpp M (orgs.) Mata Atlântica: uma rede pela floresta. RiMA, Brasília. Pp. 114-128.

Peixoto AL \& Maia LC (2013) Manual de procedimentos para herbários. Editora Universitária UFPE, Recife. 95p.

Pereira OJ \& Araújo DSD (2000) Análise florística das restingas dos estados do Espírito Santo e Rio de Janeiro. In: Esteves FA \& Lacerda LD (eds.) Ecologia de restingas e lagoas costeiras. NUPEM/ UFRJ, Macaé. Pp. 25-63.

Radford AE, Dickinson WC, Massey JR \& Bell CR (1974) Vascular plant systematics. Harper \& Row, New York. 891p.

Saiter FZ, Guilherme FAG, Thomaz LD \& Wendt T (2011) Tree changes in mature rainforest with high diversity and endemism on the Brazilian coast. Biosiversity and Conservation 20: 1921-1949.

Souza MC \& Morim MP (2008) Subtribos Eugeniinae O. Berg e Myrtinae O. Berg (Myrtaceae) na Restinga da Marambaia, RJ, Brasil. Acta Botanica Brasilica 22: 652-683.

Soares-Silva LH \& Proença CE (2006) An old species revisited and a new combination proposed in Psidium (Myrtaceae). Kew Bulletin 61: 199-204.

Soares-Silva LH \& Proença CE (2008) A new species of Psidium L. (Myrtaceae) from southern Brazil. Botanical Journal of the Linnean Society 158: 51-54.

Sobral M (2003) A família Myrtaceae no Rio Grande do Sul. Unisinos, São Leopoldo. 215p.

Sobral M (2007) Evolução do conhecimento taxonômico no Brasil (1990-2006) e um estudo de caso: a família Myrtaceae no município de Santa Teresa, Espírito Santo. Tese de Doutorado. Universidade Federal de Minas Gerais, Belo Horizonte. 360p.

Thiers B [continuously updated] Index Herbariorum: a global directory of public herbaria and associated staff. New York Botanical Garden's Virtual Herbarium. Available at <http://sweetgum.nybg. org/ih/>. Access on 17 April 2016.

Tuler AC, Carrijo TT, Nóia LR, Ferreira A, Peixoto AL \& Silva Ferreira MF (2015) SSR markers: a tool for species identification in Psidium (Myrtaceae). Molecular Biology Reports 42: 1501-1513. DOI: 10.1007/s11033-015-3927-1 
